\title{
Effect of Feeding Graded Levels of White Rot Fungi Degraded Cassava Peels on Milk Yield and Composition of West African Dwarf Sheep Milk
}

\author{
OCHEPO, G.O \\ Department of Animal Production, University of Agriculture, Makurdi, Benue State, Nigeria.
}

\begin{abstract}
Twenty lactating West African Dwarf (WAD) ewes, in a completely randomized experiment comprising four ewes per treatment, were used in a five-treatment feeding trial to study the influence of white rot fungi degraded cassava peels on milk yield and composition. Diet $T_{1}$ contained $32 \%$ undegraded cassava peels (UDCP) and served as the control, while diets $T_{2}, T_{3}, T_{4}$ and $T_{5}$ contained $8 \%, 16 \%, 24 \%$ and $32 \%$ degraded cassava peels (with Pleutrus tuber-regium) (BDCP) respectively. Five hundred grammes $(500 \mathrm{~g})$ of given experimental diets were fed to each ewe in designated animal groups daily from 8:00 - 12:00 $\mathrm{h}$ and thereafter allowed access to paddocks of natural pasture predominantly of Andropogon tectorum. Milk yield was estimated by lamb suckling method once a week for a period of 12 weeks following parturition. On the days of yield determination, lambs were separated from their dams for 4-hours (08:00 - 12:00 h), after which they were weighed to obtain the weight of the lambs before suckling and allowed to suckle the dams for $10 \mathrm{~min}$. The lambs were removed from the dams and weighed again to obtain the weight of the lambs after suckling. The amount of milk produced during the separation period (4 hours) was obtained by subtraction and multiplied by 6 to obtain daily milk production. The result showed that the experimental diets significantly $(P<0.05)$ influenced lactation yield; mean total milk yield was highest $(41.83 \mathrm{~kg})$ for ewes fed $T_{3}(16 \% \mathrm{BDCP})$. The nutrient composition of milk from ewes on the five experimental treatments were not significantly $(P>0.05)$ different. However, the Fat content of milk increased and CP decreased with BDCP inclusion in the diets. SNF and TS values were highest for ewes on $T_{3}(23.446$ and $27.193 \%$ respectively). It was concluded that the inclusion of BDCP in the treatment diets significantly increased milk yield.
\end{abstract}

Keywords: Biodegraded, cassava peels, milk yield and composition.

\section{Introduction}

Cassava peels has become an important by-product in Nigeria and is available from the local processing of cassava root for gari as well as from the newly introduced large scale plants producing gari and starch [13]. Cassava peels have been found as a source of energy in ruminant feeding system, serving either as the main basal diet or as supplement [5]. They are rarely fed fresh because of the high Cyanogenic glycoside in the material. However, sun drying, ensiling and fermentation are used to reduce the concentration of glycoside to tolerable levels [2]. Cassava peels has been upgraded through biodegradation by Solid State Fermentation technique using white rot fungi [17]. It has been reported that level of nutrition, mainly referred to as level of energy or of feed intake, is a main positive factor affecting milk yield and composition in diary ruminant. The effects of nutrition on milk composition are less clear because of interactions with the natural evolution of milk composition and through indirect effect on volume (called dilution effect) [7]. It has been observed that milk yield and milk composition are negatively correlated [11]. Due to the respective variability of milk fat and protein content, the possibilities of altering milk composition by feeding are higher for fat than for protein [20]. This study was carried out to determine the effect of feeding biodegraded cassava peels on milk yield and milk composition of West African Dwarf Sheep.

\section{Experimental Site}

\section{Materials and Method}

The experiment was carried out at the Livestock Unit of the Teaching and Research Farm of University of Agriculture, Makurdi. Makurdi is the capital of Benue State and is located on longitude $8^{\circ} 37^{1}$ East and latitude $7^{\circ} 41^{1}$ North, with annual rainfall ranges from $609.9 \mathrm{~mm}-1219.8 \mathrm{~mm}$, temperature ranges from $25.6^{\circ} \mathrm{C}$ $-39.6{ }^{\circ} \mathrm{C}$ and relative humidity of about $21 \%-85 \%$ [21].

\section{Experimental Animals and their Feeding}

Five experimental diets designated $\mathrm{T}_{1}, \mathrm{~T}_{2}, \mathrm{~T}_{3}, \mathrm{~T}_{4}$ and $\mathrm{T}_{5}$ were formulated containing $0 \%, 8 \%, 16 \%$, $24 \%$ and $32 \%$ biodegraded cassava peels respectively. Twenty lactating West African Dwarf (WAD) sheep aged between 18 and 24 months with weight between 19 and $21 \mathrm{~kg}$ from the University of Agriculture, Makurdi 
Effect of Feeding Graded Levels of White Rot Fungi Degraded Cassava Peels on Milk Yield and...

flock were used for the study. The animals were randomly allocated to the five treatments in a completely randomized design (CRD). The animals were tagged for easy identification and separation. Five hundred grammes $(500 \mathrm{~g})$ of given experimental diets were offered to designated animals groups daily before they were released to natural pasture. The trial lasted for a period of eighty four (84) days. Fresh water was served $a d$ libitum.

\section{Milk yield and Milk Composition}

Milk yield was estimated by lamb suckling method once a week for a period of 12 weeks following parturition [9]. Animals were incorporated each week as they lambed. The initial milk yield for each animal was determined at the first week post partum. Thereafter, milk yield was determined every week up till the $12^{\text {th }}$ week of lactation. On the days of yield determination, lambs were separated from their dams for 4-hours (08:00 12:00 h), after which they were weighed to obtain the weight of the lambs before suckling and allowed to suckle the dams for $10 \mathrm{~min}$. The lambs were removed from the dams and weighed again to obtain the weight of the lambs after suckling. The amount of milk produced during the separation period ( 4 hours) was obtained by subtraction and multiplied by 6 to obtain daily 24 hours milk production [6].

\section{Determination of Milk Composition}

About 50 to $100 \mathrm{ml}$ of milk samples were obtained and stored in the refrigerator at $-4{ }^{\circ} \mathrm{C}$ for analysis to determine the chemical composition of the milk. All the milk samples collected were analyzed for fat by the Rose-Gottlieb's method [19]. The crude protein content ( $\mathrm{N}$ x 6.38), lactose, total solids and ash were determined by methods [3]. Solids not-fat (SNF) concentration was derived from total solids and fat concentrations by difference. The energy value (EV) of milk was calculated using the equation developed for sheep [10]. $\mathrm{Y}=1.94+0.43 \mathrm{x}_{1}$

Where $\mathrm{Y}$ is the caloric value of milk in $\mathrm{MJ} / \mathrm{Kg}$ and $\mathrm{X}$ is the percent fat.

\section{Statistical analysis}

Data obtained from this study were subjected to two-way Analysis of variance (ANOVA) using the Minitab Statistical Software [15].

\section{Results and Discussion}

The proximate compositions and fibre fraction of the experimental diets were presented in Table 2 . The crude protein (CP) content ranged between $16.38-18.88 \%$ and is a reflection of the levels of BDCP in the diets. The levels of CP fed in this experiment are higher than the range of 9-14\% recommended as minimum requirement for maintenance and production for ruminants [1]. It has been reported that the effects of dietary protein level on milk production of early lactating ewes are mainly attributed to energy saving as a consequence of an increase in body fat mobilization [8] and utilization. The crude fibre content were 13.88, 13.64, 13.39, 13.15 and $12.90 \%$, the Ash were $13.95,14.24,14.53,14.81$ and $15.10 \%$ while dry matter were 95.20, 95.20, 95.30, 95.30 and $95.15 \%$ for $\mathrm{T}_{1}, \mathrm{~T}_{2}, \mathrm{~T}_{3}, \mathrm{~T}_{4}$ and $\mathrm{T}_{5}$ respectively. The high $\mathrm{DM}$ and CF content of the experimental diets could be due to the fact that it was prepared from dried feed ingredients which are characteristically high in CF and DM [4]. The Ca and P content were above the critical levels $(0.3 \% \mathrm{Ca} ; 0.25 \%$ $\mathrm{P})$ and would adequately meet ruminant requirements in warm wet climate [14].

The mean total milk yield and nutrient composition of milk of ewes fed graded levels of BDCP diets were presented in Table 3. The milk yield was 25.73, 41.58, 41.83, 37.37 and $37.34 \%$ for $\mathrm{T}_{1}, \mathrm{~T}_{2}, \mathrm{~T}_{3}, \mathrm{~T}_{4}$ and $\mathrm{T}_{5}$, respectively. The inclusion of BDCP in the experimental diets significantly $(\mathrm{P}<0.05)$ influenced the total 12 week lactation yield. Mean total milk yield was highest for ewes on $\mathrm{T}_{3}(41.829 \mathrm{~kg})$ fed $16 \% \mathrm{BDCP}$.

The nutrient composition of milk from ewes on the five experimental treatments were not significantly ( $\mathrm{P}>0.05$ ) different. The CP content was 5.90, 4.82, 4.58, 4.89 and $4.93 \%$, fat content was 2.67, 3.95, 3.75, 3.63 and $3.69 \%$, lactose was 2.31, 3.00, 3.39, 2.62 and $3.14 \%$, total solids was $12.69,13.01,27.19,14.76$ and 17.86 $\%$, while SNF was $10.02,9.06,23.45,11.12$ and $14.47 \%$ for $\mathrm{T}_{1}, \mathrm{~T}_{2}, \mathrm{~T}_{3}, \mathrm{~T}_{4}$ and $\mathrm{T}_{5}$, respectively. The Fat content of milk increased and CP decreased with BDCP inclusion in the diets. SNF and TS values were highest for ewes on $\mathrm{T}_{3}$ (23.446 and $27.193 \%$, respectively). The CP content recorded in this study was similar to value reported by other authors [18] [12]. The energy values $(\mathrm{MJ} / \mathrm{Kg})$ were higher, while the Fat content was lower than the values reported by these authors. The lowest $\mathrm{CP}$ value observed for ewes on $\mathrm{T}_{3}$ which recorded the highest milk yield is in agreement with other authors [16] who reported that the concentrations of both fat and protein were found to fall by about $10 \mathrm{~g} / \mathrm{kg}$ as milk production increased. This observation is also in agreement with the findings of other researchers [11] who reported that milk yield and milk composition are negatively correlated. It has reported that the effect of nutrition on milk composition are less clear because of interactions with the natural evolution of milk composition and through indirect effects of nutrition on milk volume (called dilution effect) [7]. Furthermore, these authors [7] observed that in the middle and at the end of lactation, changes in 
nutrition mainly affect the persistency and / or the body reserves reconstitution; this is why limited effects are generally observed on milk yield or composition.

\section{Conclusion}

The results suggest that inclusion of BDCP in the treatment diets significantly increased milk yield. Additional nutrient obtained from the degraded cassava peels may have been responsible for the increases observed in fat, total solids, lactose and energy value of milk of ewes fed BDCP. Cassava peels is cheap, available and it's biodegradation on farm can easily be carried out. It could be recommended that livestock farmers use BDCP to feed their lactating animals to improve milk production.

Table 1: Percentage Composition of Experimental Diets

\begin{tabular}{|l|l|l|l|l|l|}
\hline \multirow{2}{*}{ Ingredients } & \multicolumn{5}{l}{ Level of inclusion $(\%)$} \\
\cline { 2 - 6 } & $\mathrm{T}_{1}$ & $\mathrm{~T}_{2}$ & $\mathrm{~T}_{3}$ & $\mathrm{~T}_{4}$ & $\mathrm{~T}_{5}$ \\
\hline Cassava peels & 32 & 24 & 16 & 8 & 0 \\
\hline BDCP* & 0 & 8 & 16 & 24 & 32 \\
\hline Soybean & 10 & 10 & 10 & 10 & 10 \\
\hline Dried Brewer's grain & 40 & 40 & 40 & 40 & 40 \\
\hline Palm kernel cake & 12 & 12 & 12 & 12 & 12 \\
\hline Bone ash & 4 & 4 & 4 & 4 & 4 \\
\hline Salt & 2 & 2 & 2 & 2 & 2 \\
\hline Total & 100 & 100 & 100 & 100 & 100 \\
\hline
\end{tabular}

BDCP- Bio-degraded cassava peels

Table 2: Proximate Composition and Fibre Fraction of Experimental Diets(\%) (DM)

\begin{tabular}{|l|l|l|l|l|l|l|}
\hline & $\mathbf{T}_{\mathbf{1}}$ & $\mathbf{T}_{\mathbf{2}}$ & $\mathbf{T}_{\mathbf{3}}$ & $\mathbf{T}_{\mathbf{4}}$ & $\mathbf{T}_{\mathbf{5}}$ & $\mathbf{S E M}$ \\
\hline CP & 16.38 & 17.56 & 17.89 & 18.22 & 18.88 & 0.018 \\
\hline EE & 13.88 & 13.64 & 13.39 & 13.15 & 12.90 & 0.015 \\
\hline Ash & 4.23 & 4.21 & 4.19 & 4.18 & 4.16 & 0.001 \\
\hline NFE & 13.95 & 14.24 & 14.53 & 14.81 & 15.10 & 0.010 \\
\hline NDF & 51.56 & 50.35 & 50.00 & 49.64 & 48.96 & 0.146 \\
\hline ADF & 50.57 & 50.30 & 50.02 & 49.75 & 49.47 & 0.011 \\
\hline ADL & 26.30 & 26.40 & 26.49 & 26.59 & 26.69 & 0.022 \\
\hline Hemicellulose & 11.4 & 11.32 & 11.24 & 11.17 & 11.09 & 0.010 \\
\hline Cellulose & 24.27 & 23.90 & 23.53 & 23.16 & 22.78 & 0.012 \\
\hline Ca & 14.90 & 15.08 & 15.25 & 15.43 & 15.60 & 0.013 \\
\hline P & 1.78 & 1.79 & 1.80 & 1.81 & 1.82 & 0.006 \\
\hline DM & 0.42 & 0.42 & 0.41 & 0.41 & 0.41 & 0.001 \\
\hline GE MJ/kg & 95.20 & 95.20 & 95.30 & 95.30 & 95.15 & 0.015 \\
\hline
\end{tabular}

$\mathrm{T}_{1}=$ Diet containing $32 \%$ UDCP, $\mathrm{T}_{2}=$ Diet containing $8 \% \mathrm{BDCP}, \mathrm{T}_{3}=$ Diet containing $16 \% \mathrm{BDCP}, \mathrm{T}_{4}=$ Diet containing $24 \% \mathrm{BDCP}, \mathrm{T}_{5}=$ Diet containing $32 \% \mathrm{BDCP}$

$\mathrm{SEM}=$ Standard error of mean $\quad$ NDF $=$ Neutral Detergent Fibre
$\mathrm{ADF}=$ Acid Detergent Fibre
ADL =Acid Detergent Lignin

UDCP = Udegraded cassava peels

$\mathrm{BDCP}=$ Bio-degraded cassava peel

Table 3: Mean Total Yield (Kg) and Proximate Composition (\%) of Milk of Ewes Fed Graded Levels of Biodegraded Cassava Peels (BDCP)

\begin{tabular}{|l|l|l|l|l|l|l|}
\hline & $\mathbf{T}_{\mathbf{1}}$ & $\mathbf{T}_{\mathbf{2}}$ & $\mathbf{T}_{\mathbf{3}}$ & $\mathbf{T}_{\mathbf{4}}$ & $\mathbf{T}_{\mathbf{5}}$ & $\mathbf{S E M}$ \\
\hline Milk yield & $25.73^{\mathrm{b}}$ & $41.58^{\mathrm{a}}$ & $41.83^{\mathrm{a}}$ & $37.37^{\mathrm{a}}$ & $37.34^{\mathrm{a}}$ & 2.858 \\
\hline $\mathrm{P}^{\mathrm{H}}$ & 6.52 & 6.42 & 6.56 & 6.66 & 6.57 & 0.052 \\
\hline CP & 5.90 & 4.82 & 4.58 & 4.89 & 4.93 & 0.375 \\
\hline Fat & 2.67 & 3.95 & 3.75 & 3.63 & 3.39 & 0.542 \\
\hline TS & 12.69 & 13.01 & 27.19 & 14.76 & 17.86 & 3.889 \\
\hline SNF & 10.02 & 9.06 & 23.45 & 11.12 & 14.47 & 3.804 \\
\hline Lactose & 2.31 & 3.00 & 3.39 & 2.62 & 3.14 & 0.210 \\
\hline Ca & 0.25 & 0.31 & 0.30 & 0.27 & 0.26 & 0.028 \\
\hline P & 0.04 & 0.03 & 0.16 & 0.16 & 0.28 & 0.068 \\
\hline EV $(\mathrm{MJ} / \mathrm{kg})$ & 3.09 & 3.64 & 3.55 & 3.50 & 3.40 & \\
\hline
\end{tabular}

${ }^{\text {ab }}$ Means on same row with different superscripts differ significantly $(\mathrm{P}<0.05)$

SEM $=$ Standard error of mean

UDCP = Undegraded cassava Peel

$\mathrm{BDCP}=$ Biodegraded Cassava Peel (Pleurotus tuber-regium)

$\mathrm{TS}=$ Total solid, $\mathrm{SNF}=$ Solid Not Fat, EV= Energy value of milk 
$\mathrm{T}_{1}=$ Diet containing $32 \%$ UDCP, $\mathrm{T}_{2}=$ Diet containing $8 \% \mathrm{BDCP}, \mathrm{T}_{3}=$ Diet containing $16 \% \mathrm{BDCP}, \mathrm{T}_{4}=$ Diet containing $24 \% \mathrm{BDCP}, \mathrm{T}_{5}=$ Diet containing $32 \% \mathrm{BDCP}$

\section{References}

[1] Aduku, A.O. (1993). Tropical Feedstuff Analysis Table. Compiled by Aduku, A.O., Department of Aminal Science Ahamdu Bello University, Samaru, Zaria, Nigeria. p 1.

[2] Akinfala, E.O. and Tewe, O.O. (2002). Evaluation of energy and protein value of whole Cassava plant meals in growing pig diets in the tropics. Bulletin of Animal Health and Production in Africa, 50: 228-234.

[3] AOAC (Association of official Analytical chemist) (1980). Official methods of analysis. 13th edition. AOAC, Washington, Dc, US. $148 \mathrm{pp}$.

[4] Arigbede, O.M., Bolaji, O.J., Sanusi, I.M., Olanite, J.A. and Jalaosho, A.O. (2010). Nutrient and performance of West African dwarf sheep fed graded level of wild yam (Anchomanes difformis) and Pennisetum purpureum. In: Babayemi,O.J., Abu, O.A. and Ewuola, E.O. (eds). Proceedings of $35^{\text {th }}$ Conference of Nigerian Society of Animal Production, 14-17 March, 2010, University of Ibadan, Nigeria. Pp 485-488.

[5] Asaolu, V.O. and Odeyinka, S.M. (2006). Performance of West Africa Sheep fed cassava peels based diets. Nigerian Journal of Animal Production, 9: 74-84.

[6] Banda, J. W., Steinbach, J. and Zerfas, H. P. (1990). Composition and Yield of Milk from non - dairy goat and sheep in Malawii. In: Rey, B., Lebbie, S.H.B. and Reynolds, L. eds, Proceeding of the $1^{\text {st }}$ Biennial Conference of the African Small Ruminant. Pp. 460 -483 .

[7] Bocquier, F. and Caja, G. (1993). Recent advances in nutrition and feeding of dairy sheep. Proceeding of $5^{\text {th }}$ International Symposium on Machine Milking of Small Ruminants, Budapest, May, 14 - 20. Hungarian Journal of Animal Production, 1 (Suppl.): 580-607.

[8] Cowan, R.T., Robinson, J.J., Mc Hattie, I. and Pennie, K. (981). Effect of protein concentration in the diet on milk yield change in body composition and the efficiency of utilization of body tissues for milk production in ewes. Animal Production, 33: 111-120.

[9] Doney, J. M., Peart, J. N. and Smith, W. F. (1979). A consideration of the technique used for estimation of milk yield by suckled sheep and a comparison of estimates obtained by two methods in relation to the effect breed, level of production and stage of lactation. Journal of Agricultural Science. (Cambridge), 92: 123-132.

[10] Economides, S. (1986). Comparative studies of sheep and goats: milk yield and composition and growth rate of lambs and kids. Journal of Agricultural Science (Cambridge), 106: 477-484.

[11] Fuertes, J.A., Gonzalo, C., Carriedo, J.A. and San Primitivo, F. (1998). Parameters of test day milk yield and milk component for dairy ewes. Journal of Dairy Science, 81: 1300-1307.

[12] Ibeawuchi, J.A, Ahamefule,F.O. and Ringim, I.A. (2003). The influence of lactation stage on milk constituents of Sahelian goats. Nigerian Journal of Animal Production. 30(2): 259-264.

[13] Iyayi, E.A. and Tewe, O.O. (1994). Cassava feeding in small holder Livestock units. In: Bokanga, M. Essers, A. J. A., Poulter, N., Rosling, H. and Tewe, O. (eds). International workshop on cassava safety. IITA Horticulture, ISHS No. 375. Pp. 261-269.

[14] McDowell, L.R. (1985). Nutrient requirement of ruminant. In: McDowell, L.R. (ed). Nutrition of Grazing Ruminants in warm climates. Academic Press, London Pp. 21 - 34.

[15] Minitab Statistical Software (1991). Minitab Statistical Software, Rehearse 15.0. MiniTab Inc., State College, P.A. USA.

[16] Morand-Fehr, P., Blanchart G. Le, Mens, P., Remenf, F. Sanvant, D., Lenoir, J, Lamberet G; Le Taouen, J. C. and Bas P. (1986). Donnees recentes sur la composition du lait de Cherre. Journees de la Recherché Ovine et caprime, 11: 253 - 298.

[17] Ochepo, G.O. (2016). Influence of white rot fungi degradation on the nutritional value of cassava peels. International Journal of Current Research, 8(06): 33090-33093.

[18] Oguike, M.A. and Udeh, M.E. (2009). Effect of Spondias mombin 1. on milk composition of lactating West African Dearf (WAD) ewes. Nigerian Journal of Animal Production. 36(2): 335-343.

[19] Pearson, D. (1977). The chemical Analysis of Foods. $7^{\text {th }}$ edition. Chemical Publ. Coy. Inc. N.Y. 575 pp.

[20] Sutton, J. D. and Morant, S. V. (1989). A review of the potential of nutrition to modify milk fat and protein. Livestock Production Science, 23: $219-237$.

[21] TAC (2011). Makurdi weather elements records. Tactical Air Command Makurdi Metrological station. 